\title{
A PRIMEIRA UCRONIA BRASILEIRA: A CASCA DA SERPENTE E A RETIFICAÇÃO DO MUNDO
}

Jayme Soares Chaves (UERJ)

Recebido em 21 mai 2018. Jayme Soares Chaves é Mestre em Teoria da Literatura Aprovado em 25 jul 2018. e Literatura Comparada e Doutorando em Literatura Comparada pela UERJ.

Resumo: Este trabalho tem como objetivo contextualizar o romance $A$ casca da serpente, de José J. Veiga, no panorama geral dos subgêneros literários conhecidos como "história alternativa" (ou "ucronia ficcional") e "ficção recursiva", ou crossover. Justifica-se o intento não apenas por este romance ser considerado o primeiro exemplo de história alternativa na literatura brasileira, como também pelo fato de ser possível dividi-lo em duas partes bastante distintas, sendo a primeira história alternativa stricto sensu e a segunda um exemplo, ainda que problemático, de "ficção recursiva". Por outro lado, o romance não se esgota nestas duas categorias, mas se vale delas para a construção e o reforço de um mito histórico e político, como tentaremos demonstrar.

Palavras-chave: José J. Veiga; Ucronia; Crossover.

Abstract: This work aims to contextualize the novel A casca da serpente, by José J. Veiga, in the general panorama of literary subgenres known as "alternative history" (or "fictional ucrony") and "recursive fiction", or crossover. It is justified not only because this novel 
is considered the first example of alternative history in Brazilian literature, but also because it is possible to divide it into two quite distinct parts, the first being alternative story stricto sensu and the second an example, although problematic, of "recursive fiction". On the other hand, the novel is not exhausted in these two categories, but uses them for the construction and reinforcement of a historical and political myth, as we will try to demonstrate.

Keywords: José J. Veiga; Ucrony; Crossover

\section{INTRODUÇÃO}

Em 1989, Ana Miranda publicou Boca do Inferno, considerado oficialmente como o livro que inaugurou a retomada do romance histórico na literatura contemporânea brasileira. Paralelamente, verificou-se também um aumento na oferta de livros de divulgação histórica. Atesta-o, por exemplo, o sucesso em 1995 da biografia Mauá, Empresário do Império, de Jorge Caldeira, da série de Eduardo Bueno, iniciada em 1998, com A Viagem do Descobrimento, e mais recentemente, Lira Neto e sua biografia de Getúlio Vargas em três volumes e a trilogia de Laurentino Gomes e sua concentração em datas-chave da história brasileira 1808, 1822 e 1889. Sem falar no grande número de periódicos facilmente encontrados nas bancas de jornal. A televisão brasileira adiantou-se na exploração deste filão histórico: das vinte e uma minisséries produzidas pela Rede Globo na década de 1980, apenas sete não eram de temática histórica. E, curiosamente, o número de minisséries históricas foi diminuindo na década de 1990 e na primeira década do século XXI, ao mesmo tempo em que esta temática crescia na mídia impressa. Exceção sintomática, A Invenção do Brasil, escrita por Jorge Furtado 
e dirigida por Guel Arraes, foi exibida entre 19 e 21 de abril de 2000, um dia antes do aniversário de 500 anos do descobrimento do Brasil. Os onze anos que separam a primeira publicação do romance de Ana Miranda da efeméride consolidaram este fenômeno:

O romance histórico, que vem ganhando fôlego a partir da publicação de Boca do inferno (1989), de Ana Miranda, afasta o olhar do complexo presente do País e volta-se para o passado, a fim de detectar aí mitos, heróis, traços característicos, que nos ajudem a ver-nos, hoje. Temos uma tradição a ser resgatada e preservada e que, em sua continuidade, pode fornecer elementos de (re)construção de nossa identidade abalada, num momento em que não estamos coincidindo com nós mesmos (...) Neste revival, que tem tido boa acolhida da crítica e do público, levando as editoras, de olho no mercado consumidor, a aumentar o número de títulos do gênero, vê-se o resgate da memória nacional ligado a uma certa desesperança quanto ao futuro do país, na opinião de Luiz Schwarz, da prestigiosa Editora Companhia das Letras, que praticamente inaugurou a onda com o primeiro romance de Ana Miranda. (GOMES, 2006, p.123)

É a opinião de Esteves:

Nesse fim de milênio as comemorações do $V$ Centenário do Descobrimento do Brasil, mais interessadas em fazer circular mercadorias que discutir os sentidos do descobrimento, movimentaram os meios culturais do País, e evidentemente também o mercado editorial. (ESTEVES Apud OLIVEIRA, 2014, p.25)

Na mesma página, Oliveira também cita o crítico Seymour Menton, que em seu livro La Nueva Novela Histórica de La América 
Latina 1979-1992, emite parecer idêntico em relação ao boom do romance histórico latino-americano:

A mi juicio, el fator más importante en estimular la creación y la publicación de tantas novelas históricas em los três últimos lustros há sido la aproximación del quinto centenário del descubrimiento de America. (MENTON Apud OLIVEIRA, 2014, p.25)

É, no mínimo, curioso que 1989 tenha sido o ano inaugural tanto dessa nova leva de romances históricos, quanto de seu negativo, de sua contraparte contrafactual. Pois no ano de 1989 também foi publicado A casca da serpente, de José J. Veiga. Ao que tudo indica, é o primeiro romance de história alternativa, ou ucronia, da literatura brasileira. E como Boca do Inferno, também foi um marco inaugural, pois em paralelo ao aumento da oferta de romances históricos e de livros e revistas de divulgação (ou vulgarização) histórica, surgiu uma corrente de histórias alternativas, ou ucronias, que por sua vez deu origem ao steampunk entre os escritores de ficção científica brasileiros. Ao contrário do steampunk estadunidense, que inicialmente surge como "fantasia vitoriana" (VANDERMEER, CHAMBERS, 2011, p.48) para depois configurar-se e/ou amalgamar-se com a história alternativa, a ucronia ficcional e a mitopoética, o steampunk brasileiro sempre esteve estreitamente ligado ao subgênero história alternativa. Mas uma vez que não parece ter sido a intenção de Veiga inaugurar ou se filiar a determinado subgênero literário, costuma-se atribuir a primazia ao conto "A Ética da Traição", de Gerson Lodi-Ribeiro, publicado em 1992 no último número do periódico Isaac Asimov Magazine de Ficção Científica. 
Além do seu pioneirismo em história alternativa, Veiga também lança mão, em seu romance, de um procedimento conhecido como ficção recursiva, ou crossover, muito comum no steampunk. Tornase necessário, portanto, definirmos esta prática, bem como o subgênero a que o romance pertence.

\section{HISTÓRIA ALTERNATIVA E HISTÓRIA CONTRAFACTUAL}

História alternativa, ou ucronia, é um gênero ou subgênero literário, comumente associado à ficção científica e à literatura fantástica, no qual o enredo se desenvolve em determinada época histórica que teve o seu desenvolvimento, tal como o conhecemos, parcial ou alterado graças a uma hipotética variação em um ou mais pontos decisivos. Ou, no dizer de Lodi-Ribeiro:

Histórias Alternativas são trabalhos de ficção ou não-ficção que narram uma sucessão de eventos hipotéticos, de natureza qualquer, construindo um presente ou passado diferente daquele que aceitamos como verídico. Esta construção é elaborada a partir do pressuposto que, em algum ponto de um passado ainda mais remoto, algum acontecimento histórico não ocorreu nessa linha temporal alternativa de forma idêntica à que sabemos ter ocorrido em nossa própria linha temporal. $(2003$, p.1)

Complementando a definição acima, cumpre ressaltar que, no caso da não-ficção, ou seja, o estudo histórico, utiliza-se preferencialmente o termo "história contrafactual" (do latim contra facta, contra os fatos) ou "história virtual". A história contrafactual é um campo específico dos estudos históricos que procura criar cenários hipotéticos para eventos da História com o objetivo de 
melhor compreender o que de fato aconteceu. A pergunta básica da história contrafactual é what if? A partir desta pergunta inicial, os contrafactualistas criam cenários hipotéticos, possibilidades alternativas a partir de um assim chamado "ponto de divergência", às vezes um detalhe, que poderia desencadear tal mudança no rumo dos acontecimentos que suas consequências poderiam alterar o curso da história por décadas, talvez séculos. Ou por outro lado, uma determinada mudança no curso da história que não modifica, ou, pelo menos, não substancialmente, o resultado conhecido. Os primeiros historiadores não se furtaram em exercer algum tipo de contrafactualismo. Um exemplo clássico é Tito Lívio, que em sua História de Roma imagina possibilidades alternativas para as conquistas de Alexandre Magno. Ou Tucídides, que em sua História da Guerra do Peloponeso elabora mais de vinte alternativas para o resultado dos confrontos entre Atenas e Esparta. Ou Edward Gibbon e sua famosa especulação sobre os minaretes de Oxford, consequência de uma hipotética derrota de Carlos Martel na Batalha de Poitiers.

Assim, a história contrafactual é definida de modo sucinto por Richard J. Evans, um crítico do contrafactualismo, como a elaboração de "versões alternativas do passado em que uma alteração na linha do tempo leva a um resultado diferente daquele que sabemos que de fato ocorreu" (EVANS, 2014, p.1).

Um retrospecto histórico e crítico do contrafactualismo é feito por Niall Ferguson, que, ao contrário de Evans, é um defensor de sua prática em História. No ensaio "Virtual History: Towards a 'chaotic' theory of the past", introdução ao volume por ele organizado, Virtual History: Alternatives and Counterfactuals, Ferguson enumera alguns 
dos problemas que dificultariam a aceitação desta metodologia nos círculos acadêmicos. Segundo ele, existem

dois tipos distintos de contrafactuais que foram usados pelos historiadores: aqueles que são essencialmente os produtos da imaginação, mas (geralmente) não têm base empírica; e aqueles projetados para testar hipóteses por (supostamente) meios empíricos que evitam a imaginação em favor do cálculo. No caso do primeiro, é a tendência de se confiar na retrospecção para inspirar ou postular explicações reducionistas, o que leva a implausibilidade. No caso do segundo, é a tendência de fazer suposições anacrônicas. (FERGUSON, 1999, p.18)

Outro problema é que os exercícios contrafactuais permaneceram, e permanecem, por um longo período de tempo, desde o século XVIII, geralmente como textos satíricos, ficcionais e semificcionais. Não surpreende que, na primeira reunião de ensaios em história alternativa, publicada em 1931 e organizada por Sir John Collings Squire, a maioria dos colaboradores fosse antes composta de escritores do que historiadores de fato: Hillaire Belloc, G.K. Chesterton, Winston Churchill, Ronald Knox, Emil Ludwig e André Maurois. Este híbrido de literatura e ensaio histórico, evidentemente, serviu para tornar a fronteira entre a ficção e a não-ficção, em matéria de counterfactuals, bastante tênue, o que teria, segundo Ferguson, contribuído para o pouco apreço do contrafactualismo no meio acadêmico.

Pensemos, por exemplo, no recente romance de Robert Harris, Fatherland, uma história de detetive situada em uma Europa imaginária, vinte anos após uma vitória nazista. Como esses livros costumam 
ser, é bem pesquisado. Mas é irremediavelmente ficcional, na medida em que a narrativa segue o padrão clássico de um thriller popular e assim, tende a diminuir a plausibilidade do cenário histórico. Em vez de ser uma catástrofe que quase aconteceu - e para evitá-la, milhões pereceram - uma vitória nazista na Segunda Guerra Mundial torna-se apenas um pano de fundo excitante para uma boa história de se ler na sala de embarque do aeroporto. Inúmeras outras obras de ficção afirmam essas premissas históricas contrafactuais: Kingsley Amis, em The Alteration, que desfaz ansiosamente a Reforma Inglesa, é outro bom exemplo. Mas eles não têm mais a ver com a história do que os livros de "futurologia", que a Biblioteca de Londres educadamente classifica como "história imaginária". Futurólogos oferecem adivinhações sobre qual das alternativas plausíveis que nos confrontam hoje vai prevalecer nos próximos anos, e geralmente baseiam suas previsões na extrapolação de tendências passadas. A julgar pela exatidão de tais obras, no entanto, elas poderiam muito bem ser baseadas em astrologia ou cartas de tarô. (FERGUSON, 1999, p.7-8)

Ao contrário de Ferguson, Evans vê uma convergência entre a história contrafactual e a literatura de ficção, particularmente a ficção científica que se dedica a tais especulações:

Reescrever o passado tem sido apreciado pelos autores de romances de ficção científica e de filmes que envolvem viagens no tempo. De fato, história alternativa é um subgênero reconhecido no mundo da ficção científica. Todas essas obras notáveis de ficção e não-ficção compartilham algo em comum na virada cultural pós-moderna que começou no final do século passado. O colapso das grandes ideologias do século 20, sobretudo do marxismo, 
abriu o passado a uma multiplicidade de trajetórias possíveis. (...) O pós-modernismo encorajou uma indefinição das fronteiras entre passado e presente, entre verdade e ficção; ele enfraqueceu conceitos lineares de tempo e introduziu uma forte ênfase na subjetividade do historiador. (...) A história contrafactual pertence essencialmente a este novo mundo de realidades alternativas, mesmo que seus proponentes possam rejeitar abordagens pósmodernas do passado. (EVANS, 2014, p.30)

Enquanto Ferguson procura separar o contrafactualismo dos exercícios satíricos e ficcionais, de modo a configurar uma metodologia, Evans, recusando essa metodologia, não vê diferenças entre eles. Ambos consideram que a maior parte do que já se produziu no tema é apenas fantasia, desprovida de rigor científico. 0 que os coloca em direções opostas é que Ferguson, ao contrário de Evans, defende o estatuto metodológico da história contrafactual.

De qualquer forma, existe entre ambas algo em comum: o what if, o ponto de divergência. Em sua introdução para um dos mais interessantes romances de história alternativa, $O$ agente de Bizâncio (1987), de Harry Turtledove, Isaac Asimov assinala que

Não é fácil escrever uma história de um "se" da história. Uma pequena alteração pode originar outra e ainda outra, até um período posterior se tornar radical, quase incrivelmente diferente do que hoje consideramos ser a realidade. Ou, em alternativa, pode gerar uma diferença que, através de qualquer espécie de inércia social, consiga convergir até um período posterior quase idêntico ao que chamamos realidade, exceto algumas mudanças curiosas - ou irônicas. (ASIMOV Apud TURTLEDOVE, 1988, p.8) 
Isso vale tanto para o ficcionista quanto para o historiador, e embora o ficcionista, ao contrário do historiador, esteja mais livre para dar asas à imaginação, ambos, na opinião de Ferguson e Asimov, deveriam manejar suas ferramentas com mais precisão, dentro de certas regras.

\section{FICÇÃO RECURSIVA, CROSSOVER, TRANSFICCIONALIDADE}

O segundo subgênero, ou melhor, procedimento, ao qual A casca da serpente pode ser associado, é o crossover, ou ficção recursiva. Apesar de ser possível usar o termo de forma genérica, o debate teve início no âmbito da ficção científica, a partir da constatação de uma prática relativamente comum entre escritores do gênero: a utilização de tramas, enredos, personagens e universos de outros escritores. Digo que existe alguma discussão por causa da relevância de dois conceitos ligeiramente diferentes: a New Glande Science Fiction Association (NESFA), uma das mais antigas dedicadas ao assunto, defende que ficção científica recursiva é aquela cujos enredos giram em torno de personagens que são escritores de ficção científica no mundo real. Como afirma o físico nuclear e fundador da NESFA Anthony R. Lewis, autor de uma bibliografia sobre o assunto:

De acordo com o Oxford English Dictionary (Nova York, 1971 AD), a palavra "recursão" é rara ou obsoleta e significa "um movimento para trás ou um retorno". Isso dificilmente se aplica ao que eu quis dizer. A nona edição do New Collegiate Dictionary de Webster (Springfield, Massachusetts, 1986 A.D.) chega mais perto com "a determinação de uma sucessão de elementos ... por operação em um ou mais elementos precedentes de acordo 
com uma regra ou fórmula envolvendo um número finito de passos." Para nossos propósitos, a melhor definição vem da Encyclopedia Galactica, 116th Edition (Terminus, $1020 \mathrm{FE}$ ) onde, em um artigo sobre a matemática da psico-história, o termo é discutido e se observa "... No entanto, o uso comum da palavra, a partir de seu significado matemático, passa a ser sinônimo de "auto-referencial". Ou seja, qualquer entidade ou item que aponte para si mesmo pode ser considerado "recursivo". (...) Há histórias de ficção científica que se referem à própria ficção científica. As referências podem ser de autores, fãs, colecionadores, convenções, etc. Mary Shelley, HG Wells, Edgar Allan Poe, Philip K. Dick e Isaac Asimov são cinco dos mais populares escritores de ficção científica a serem escalados como personagens (embora nós atualmente não conhecemos nenhuma história que contenha todos eles). (LEWIS, 1990)

Ou seja, em um primeiro momento, Lewis limita a função da recursividade ao uso de escritores de FC como personagens. Uma espécie de metaficção científica. Mas ele ainda assinala uma variação, que ele chama de crossover: uma história de determinado autor onde aparecem personagens de outros autores.

Já The Encyclopedia of Science Fiction de John Clute e Peter Nichols, obra de referência na matéria, assim define a FC recursiva:

Reciclar material do vasto e crescente depósito do que já foi escrito tem sido uma prática de escritores de ficção científica. Tramas e personagens reaparecem constantemente em toda a FC, geralmente, mas nem sempre, na forma de sequências escritas pelo autor da obra original; lugares (como o planeta Marte de Edgar Rice Burroughs) se tornam acessórios universais; e 
termos descritivos de artefatos ou circunstâncias exclusivas de FC (...) tendem, uma vez introduzidos, a se tornarem uma linguagem comum. Quando Robert A. Heinlein fez referência, em "O Número da Besta" (1980), a personagens e situações que apareceram em romances anteriores escritos por ele e por outros escritores de FC, ele estava operando dessa maneira tradicional. Mas quando ele introduziu no mesmo livro pessoas - escritores, editores, fãs - que estiveram envolvidos com a própria FC, ele fez algo muito diferente, algo que marcou sua carreira e o gênero no qual o livro se insere, aproximando-se de um fase recente e autoreferencial. (CLUTE; NICHOLS, 1999)

E mais adiante, o trecho fundamental:

Em termos mais amplos, a FC recursiva pode ser definida como histórias que consideram as pessoas reais e os mundos fictícios que habitam em seus sonhos, como se compartilhassem graus equivalentes de realidade. É, em outras palavras, uma técnica que pode ser usada para criar histórias alternativas, geralmente retrospectivas no tempo, e frequentemente expressando uma nostalgia poderosa por passados em que as visões do início do gênero SF, de fato, se tornam realidade. (CLUTE; NICHOLS, 1999)

Esta definição é mais útil para o propósito deste trabalho, pois ao invés de separar de maneira rígida a recursividade do crossover, unifica os dois conceitos sobre o pano de fundo das histórias alternativas. Apesar de Lewis não deixar explícito, o crossover pode ocorrer não apenas entre personagens de vários livros de diferentes autores, mas também entre estes personagens e seus autores transformados em personagens. Implicitamente, a definição de 
Clute e Nichols corrobora esta ideia. Por "pessoas reais e os mundos fictícios que habitam em seus sonhos", podemos sem dúvida incluir não apenas ideias como também enredos e personagens. De modo mais abrangente, poderíamos dizer que a toda ficção recursiva se vale de personagens reais e/ou fictícios e de seus mundos, ficcionais ou não, que compartilham graus equivalentes de realidade para criar histórias alternativas. Isso abre o leque de tal modo que podese correr o risco de, ao retirar aquilo que era específico do gênero da ficção científica e aplicar em qualquer narrativa que se utilize destes procedimentos, substituir um conceito por uma platitude.

A palavra crossover possui múltiplos significados em inglês, e mesmo em literatura ela pode ter dois sentidos: crossover fiction pode se referir a um tipo de literatura direcionada tanto para crianças como para adultos, como também pode se referir a um recurso no qual um ou mais personagens oriundos de diferentes universos ficcionais e/ou de diferentes autores compartilham outro universo ficcional, ou seja, um mundo ficcional construído com pedaços de outros mundos ficcionais. É a essa segunda categoria, subgênero ou procedimento, que eu vou aludir. Mas, para evitar a confusão entre as duas acepções do termo crossover, talvez fosse útil adotar a nomenclatura criada por Richard Saint-Gelais em 2001: transficcionalidade. Sua definição, publicada na Routledge Enciclopedy of Narrative Theory:

Dois (ou mais) textos exibem uma relação transficcionalquandoelescompartilhamelementos, tais como personagens, lugares imaginários, ou mundos ficcionais. A transficcionalidade pode ser considerada como um ramo da intertextualidade, mas geralmente esconde esta ligação intertextual 
porque não cita e nem reconhece suas fontes. Ao contrário, ele usa o cenário e / ou os habitantes do texto de origem como se eles existissem independentemente. (SAINT-GELAIS, 2010, p.785)

Ou, sinteticamente, segundo Marie-Laure Ryan, é uma "migração de entidades ficcionais de diferentes textos" (2013, p.100), ou de diferentes mídias. Saint-Gelais também afirma que a transficcionalidade pede uma abordagem multidisciplinar, em conjunto com as teorias dos "mundos possíveis" e dos "universos narrativos". Sobre este último, Ryan, citando Lubomir Dolezel, diz que as relações entre um universo narrativo e outro podem se dar por expansão, modificação e transposição. A expansão ampliaria o universo narrativo original pelo acréscimo de novos elementos ou pela transformação de personagens secundárias em heróis. Sobre isso cabe dizer que toda ficção recursiva trabalha por expansão. A modificação é o what if?, é o counterfactual aplicado a narrativas ficcionais. A transposição é o deslocamento de elementos da narrativa original para uma ambientação temporal ou espacial diferente.

O pesquisador Jess Nevins (2003, p.175) enumerou alguns tipos possíveis de crossover. Podemos destacar: a fusão de mitos, a utilização de personagens recorrentes na obra de um único autor, a reunião de personagens de determinado autor feita por outro autor, reuniões de personagens de vários autores concebidas por outro autor, reunião de pessoas reais e figuras históricas como se fossem ficcionais, etc. Não vamos exemplificar exaustivamente cada um desses tipos de crossover, mas apenas como ilustração: em relação ao primeiro tipo, a fusão de mitos, remetemo-nos quase imediatamente ao mito de Jasão e os Argonautas. Nada menos do 
que 50 entidades mitológicas participam da empreitada, algumas bem conhecidas como Héracles, Orfeu, Castor e Pólux, etc. No segundo tipo os exemplos mais famosos são, sem dúvida, a Comédia Humana de Balzac, e o ciclo Rougon Marcquat de Zola. Dumas (pai) também vai usar esse recurso em seus romances históricos e Júlio Verne vai criar com suas Viagens Extraordinárias todo um universo ficcional autorreferente.

Devo dizer que, a essa lista, eu acrescentaria dois outros tipos: mundos ficcionais onde personagens reais conviveriam com personagens ficcionais, incluindo escritores e seus próprios personagens, como em Frankenstein Libertado, de Brian Aldiss (1988), onde todos os personagens do romance de Mary Shelley compartilham com a própria Mary Shelley, além de Percy Shelley e Lord Byron o mesmo universo ficcional criado por Aldiss. O outro tipo de crossover que eu acrescentaria à lista de Nevins seria o oposto ao quinto tipo: reunião de personagens fictícios como se fossem pessoas reais. Uma espécie de biografia ficcional, ou combinação de biografias ficcionais, diferentes das biografias ficcionais escritas, por exemplo, por Jorge Luis Borges em História Universal da Infâmia, ou Marcel Schwob em Vidas Imaginárias, uma vez que, em ambos os casos, as biografias são ficcionais, mas os personagens realmente existiram ${ }^{1}$.

Desnecessário dizer que todos esses tipos de crossover são intercambiáveis. E é no último tipo da lista de Nevins que podem caber todos os outros em infinitas combinações: a construção de 1 Jorge Luis Borges, em seu Um ensaio autobiográfico (2000), ao salientar a diferença entre o seu livro e o Vidas Imaginárias, de Marcel Schwob, do qual se confessa devedor, diz que leu sobre a vida de pessoas conhecidas e modificou e deformou tudo, a seu bel-prazer, enquanto Schwob inventou "biografias de homens reais sobre os quais há escassa ou nenhuma informação". 
mundos ficcionais habitados por personagens de diversos mundos ficcionais criados por diversos autores. Em outras palavras, todo um universo transficcional. É um jogo de regras mais ou menos rígidas. Por mais que o autor liberte a sua imaginação para fazer as conexões mais surpreendentes entre os personagens mais improváveis, é necessário um profundo conhecimento dos textos originais e, à maneira de Schwob, preencher eventuais lacunas.

Mas abrir esse leque, no caso de uma análise de $A$ casca da serpente, que não é ficção científica, mas sem dúvida é história alternativa, e sem dúvida se utiliza da recursividade, parece-nos pertinente.

\section{A CASCA DA SERPENTE: ROMANCE INAUGURAL}

A casca de serpente, romance de José Jacintho Veiga publicado em 1989, é, como já havíamos dito, o romance inaugural em história alternativa no Brasil. O cenário é o fim da Guerra de Canudos. O ponto de divergência: Antônio Conselheiro não morreu; foi retirado vivo e muito doente por um grupo de jagunços, três dos quais facilmente identificados com figuras históricas reais. São eles: Joaquim Norberto, "predestinado à chefia suprema nos últimos dias de Canudos" (CUNHA, 2002, p.313); Quim Pisapé ou Joaquim Tranca-pés, "guerrilheiro sanhudo" (CUNHA, 2002, p.312); e Bernabé (José) de Carvalho, “...tipo flamengo, lembrando talvez, o que não é exagerada conjectura, a ascendência de holandeses que tão largos anos por aqueles territórios do norte trataram com o indígena" (CUNHA, 2002, p.773); além de Pedrão. Enterram um homem de nome Balduíno, que morrera no bombardeio de 22 de setembro e que era constantemente confundido com o Conselheiro e enviam Antônio Beatinho, "mulato espigado, magríssimo, adelgaçado pelos 
jejuns... meio sacristão, meio soldado, misseiro de bacamarte..." (CUNHA, 2002, p.313) e Bernabé aos federais para divulgar a falsa notícia da morte do seu líder. Deixando no arraial cerca de noventa combatentes para lutar até o último homem, o grupo escapa pelas veredas de Uauá e Várzea da Ema, em direção ao norte, carregando o combalido Conselheiro. Depois de algum tempo acampados na serra da Canabrava, o Conselheiro, já convalescido, decide estabelecer uma nova comunidade em um lugar chamado Itatimundé, na serra da Ariranga, lugar para ele mítico por evocar as lembranças de sua "iluminação espiritual", quase trinta anos antes da tragédia de Canudos².

A nova comunidade seria fundada em bases muito diferentes da original. Seus alicerces emergiriam a partir das transformações do Conselheiro, internas e externas. O Conselheiro paulatinamente abandona o autoritarismo decorrente de sua aura messiânica e passa a deliberar com o grupo as decisões a serem tomadas. Em seguida, passa a afrouxar o rigorismo religioso, diminuindo e até mesmo abolindo o número de rezas, bênçãos e mortificações. Mais tarde, passa a se preocupar com alimentação, higiene e com a própria imagem, tomando banho, abolindo a túnica azul e cortando a barba e o cabelo. Finalmente, deixa de ser Antônio Conselheiro e passa a ser, simplesmente, tio Antônio. A serpente mudou de casca.

Corre a notícia de que uma nova Canudos estava se formando, e várias pessoas começam a se juntar ao grupo inicial. A partir da página 89 (primeira edição da Bertrand Brasil, 1989), o romance

2 Período do qual nada se sabe. Veiga reconstrói esse momento a maneira de Marcel Schwob em Vidas Imaginárias, inventando fatos onde existem lacunas. 
lança mão da recursividade e tem aí o início do desfile de personagens históricos, a maioria alheia ao universo canudense, que surgem como que por mágica na comunidade nascente. São eles, por ordem de entrada em cena: dois aventureiros irlandeses, James Connolly (ou, em gaélico, Séamas Ó Conghaile, sindicalista, republicano e líder socialista irlandês, nascido em Edimburgo em 1868 e executado em 1916 após a fracassada Insurreição da Páscoa, em Dublim) e Patrick Pearse (ou Pádraig Anraí Mac Piarais, professor, poeta e ativista nascido em Dublin em 1879 e morto na mesma ocasião que Connolly, em 1916); Militão Augusto de Azevedo (18371905), fotógrafo, autor do Álbum Comparativo de Vistas da Cidade de São Paulo (1862-1867); Francisca Edwiges Neves Gonzaga, a Chiquinha Gonzaga (1847-1935), compositora; Orville Adalbert Derby (1851-1915), geólogo e geógrafo norte-americano que viveu e morreu no Brasil, autor de trabalhos fundamentais para as descrições de Euclides da Cunha na primeira parte de Os Sertões, "A Terra"; e, finalmente, Pedro, o príncipe Pyotr Alexeyevich Kropotkin (1842-1921), filósofo anarquista russo. Cada um deles carrega o seu próprio "contrafactual", sua própria história alternativa, sua própria vida imaginária. E todos eles, de uma forma ou de outra, contribuem para o advento da Concorrência de Itatimundé, a nova Canudos, que não apenas prospera, mas se torna um modelo para outras comunidades ao redor do mundo até ser destruída "pelos invasores em 1965" (VEIGA, 1989, p.155).

O romance pode ser dividido claramente em duas partes, sendo a primeira uma ucronia stricto sensu, e a segunda, um crossover literário entre figuras históricas provenientes de contextos díspares. 


\section{O PONTO DE DIVERGÊNCIA}

Vamos nos deter agora no desenvolvimento do ponto de divergência que domina a primeira parte do romance. O Conselheiro não morreu, e sua progressiva transformação em tio Antônio começa já nos estertores do arraial, diante da catástrofe que se tornou a aventura de Canudos. Após o grupo de jagunços deliberar sobre a possibilidade de fuga proposta por Baianinho Gonçalves, o Beatinho pergunta ao Conselheiro se ele havia escutado: "O Conselheiro demorou a falar, e quando falou, com dificuldade, foi para dizer que tinha ouvido, mas não queria opinar para não parecer que estava forçando" (VEIGA, 1989, p.9).

José J. Veiga não perde tempo. A desconstrução da imagem clássica do Conselheiro tem início em um momento altamente improvável, no calor dos últimos combates, doente, sem o tempo necessário para reflexão ou para o amadurecimento de uma nova ideia.

Em seguida, no início da fuga, o Conselheiro relaxa nas rezas porque

não convinha agravar os embaraços naturais com rigores de protocolo, talvez fosse com esse pensamento que o Conselheiro, antes tão exigente em questões de disciplina e cerimonial, agora preferisse fechar os olhos. (VEIGA, 1989, p.15)

Após o que, sentindo a urgência das necessidades fisiológicas, declara para o bando: "Quero ir no mato". (VEIGA, 1989, p.15)

A narrativa prossegue na desconstrução, fazendo com que o beato, "com seu gesto de levantar a mão, o que lhe dava aquele ar de Jesus Cristo de gravura" explicasse que "enquanto se aliviava esteve também meditando, e nesse meditar recebeu uma inspiração 
alvissareira, talvez mesmo salvadora" (VEIGA, 1989, p.17). Não é a única vez, no romance, que a meditação e a inspiração se associam ao ato de defecar. Algumas páginas adiante, Dedé de Donana é atacado de diarreia e desesperadamente baixa as calças na presença do Conselheiro e se alivia em cima da bota de Bernabé, o que provoca uma série de incidentes grotescos na tentativa de ajudar o companheiro a limpar a bota. Durante toda a cena, Bernabé olha para o Conselheiro "que até então parecia alheio a tudo, afundado em seus pensamentos ou em suas orações" mas

estava era muito atento ao que se passava em volta. Podia ser então que quando ele parecia distante, cochiloso, caducante, era porque tinha se acendido para o lado de dentro e entrado em comunicação com alguma força invisível para os outros e da qual recebia o sustento para a alma e para o corpo" (VEIGA, 1989, p.21)

A precedência das preocupações materiais sobre as espirituais já surgia um pouco antes, quando o beato reclama que ninguém havia pensado em preparar a janta, "justamente o único do bando que não ligava a comida" (VEIGA, 1989, p.19).

Vimos até agora, que nas primeiras vinte páginas do livro, já se apresentam as três linhas gerais de mudanças no comportamento do Conselheiro. Podemos destacá-las com alguns exemplos que as ilustram.

Esta é a primeira grande ironia do romance de José J. Veiga: o Conselheiro torna-se um democrata. Ao democratizar-se, o Conselheiro se aproxima daquilo que combatia, daquilo que a visão moderna identifica automaticamente com o ideal republicano. Primeiro, como já foi citado, ele se recusava a opinar sobre a ideia da fuga "para não parecer que estava forçando". Depois, após sua 
primeira "inspiração" ao aliviar-se, sugere permanecer no alto da serra até o exército ir embora. E pergunta: "O que é que vocês acham?" (VEIGA, 1989, p.17)

Quando chega a notícia de que o exército finalmente se retirara, o Conselheiro institui o sufrágio universal no grupo: "Todo mundo opina, depois conta os votos, e o que a maioria decidir, fica valendo" (VEIGA, 1989, p.46-47).

E assim, progressivamente, todos os assuntos importantes passam a ser decididos coletivamente. Várias falas do Conselheiro reforçam esta mudança: "Ando pensando cá umas coisas, e desejo saber a opinião dos senhores" (p.47); "Antes eu resolvia tudo sozinho e dava ordens. Isso vai mudar, aliás já mudou" (p.48); "Como eu disse, não quero mais decidir sozinho" (p.50).

Mas o Antônio Conselheiro de José J. Veiga, quando adota princípios democráticos, não o faz por inteiro. Em uma das primeiras discussões coletivas, declara que a partir daquele momento, "cada um aqui tem obrigação de dizer o que pensa (...) Por enquanto é obrigação, quando se acostumarem passa a ser um direito" (p.48). Em outro momento, reflete:

Era difícil levar essas ideias aos jagunços sem decepcioná-los, e ele mesmo não estava sabendo como fazer sem forçar a mão. $O$ chefe que não sabe tirar as dúvidas de um chefiado deve desistir da chefia. Então, enquanto os homens não aprendessem o caminho do novo viver, ficariam ali, ele martelando. Até nos assuntos mais corriqueiros. (VEIGA, 1989, p.52)

Para os propósitos do romancista, à democratização da relação entre a nova comunidade e o seu líder, seguir-se-ia necessariamente 
a sua laicização. O relaxamento da prática religiosa começa mal o bando se põe em fuga, a princípio como uma necessidade diante da urgência da situação. Mas, dez dias depois, o Conselheiro diz a Bernabé que "era preciso evitar os erros de Canudos, formar outro arraial mais voltado para as necessidades das pessoas, não se perdendo tanto tempo com rezas (VEIGA, p.27 - grifo nosso).

Quando Pedrão e Quero-Quero retornam da missão de reconhecimento nas ruínas de Canudos, trazendo com eles o menino Dasdor, este se ajoelha diante do Conselheiro ressuscitado e pede a benção. "O Conselheiro benzeu-o mecanicamente". E depois diz:

- De agora em diante, acabam as benças e ajoelhações. Agora só quem ainda toma bença aqui é o Dasdor, porque é órfão e ainda não tem barba. Não quero mais bodes velhos se ajoelhando pra mim e babando na minha mão. Basta um bom dia, um suscristo.

- Nem de manhã cedo, meu bom Jesus? - Era o Bernabé perguntando.

- Basta um suscristo-repetiu o Conselheiro em um tom que encerrava o assunto. (VEIGA, 1989, p.30-31)

É evidente por este trecho que o Conselheiro, assim com pretende impor a democracia (se é permitido tal paradoxo), também pretende impor o estado laico. O conforto material vai ocupando o lugar da ascese religiosa, apesar da justificativa para essa mudança se amparar na religião: "O tempo que antes era gasto em orações, agora seria empregado em obras para melhorar a vida das pessoas, evitar aqueles sofrimentos do corpo que até entopem a comunicação com Deus". Mas o Conselheiro vai ainda mais longe: sonha em criar um "mundo retificado", um "novo céu e uma nova 
terra", como disseram "o salmista, o profeta, o discípulo amado", o Velho e o Novo Testamento. Sem dificuldade em enxergar nos textos bíblicos uma preparação para as mudanças que haviam de vir, incluindo nelas os seus próprios planos, ele chega à conclusão de que "era tempo mais de ler a Bíblia, em vez de ficar rezando a esmo, como antigamente (...) Desde então, a leitura da Bíblia passou a acontecimento diário na serra." (VEIGA, 1989, p.54-55).

Trabalhar, ler a Bíblia. E aí temos mais uma notável desconstrução operada por José J. Veiga: a laicização da nova comunidade traz a reboque um sutil protestantismo. Além da democracia, então identificada com regimes republicanos, o Conselheiro se aproxima de outro antigo inimigo, o protestantismo, que antes qualificara, em seus sermões sobre os Dez Mandamentos, de "seitas que o demônio tem introduzido no mundo por seus sequazes" (NOGUEIRA, 1978, p.116).

Um curioso trecho mostra que o pensamento do Conselheiro estava adotando um conceito típico daquilo que caracterizaria certo evangelismo neopentecostal:

Se uma pessoa ou um povo tem direito a um benefício, não será ofensa a Deus, ou no mínimo impertinência, estar cutucando ele com rezas para ele não se esquecer de deferir um direito? Então ele é relaxado em suas obrigações? É, esse assunto das rezas precisa ser muito bem pensado. (VEIGA, 1989, p.27)

Temos aí um distanciamento teológico da antiga prática da contrição como preparação para o Advento, o fim do mundo, para uma visão contratualista, em que o fiel tem direitos e Deus, obrigações, onde o melhor a fazer é cuidar das "necessidades das pessoas, não se perdendo tanto tempo com rezas" e "falar a Deus 
com clareza, já depois de terem trabalhado em coisas úteis para elas, e comido com decência." (VEIGA, 1989, p.27).

Este trabalho não pretende, obviamente, tentar provar teses a respeito de indícios de práticas religiosas de cunho neopentecostal nas novas diretrizes do Conselheiro tal como José J. Veiga as concebe. Basta, no momento, ressaltar que não há contradição absoluta entre laicização e protestantismo. Na verdade, esta conduzirá àquela. Lembremos que construir e reparar igrejas, capelas e cemitérios era uma das atividades mais constantes do Conselheiro, e que a Igreja Nova de Canudos foi, segundo Euclides da Cunha, a sua "obraprima" (CUNHA, 2002, p.307), além de símbolo tenaz da resistência. Mas quando Baianinho Gonçalves imagina a possibilidade de erguer uma igreja na serra da Ariranga e Dedé de Donana faz suas objeções, Baianinho desconversa, afirmando que estava "só cismando", e que o Conselheiro não estava mais "aferrado a rezas", no que Sinfrônio de Quipapá comenta: "Eu cá sempre achei que reza demais amolece os miolos" (VEIGA, 1989, p.77-78). E não mais se fala ou se alude a construção de igrejas no novo arraial, até o fim do romance.

Depois de mudar o sistema político e o sistema religioso, era preciso mudar a imagem. E a mudança da imagem começa com uma espécie de ablução, um banho numa cacimba natural formada por uma queda d'água na subida da Canabrava: "Outro episódio que deixou os homens embasbacados foi o do banho. Em Canudos nunca se soube que o Conselheiro tomasse banho." (VEIGA, 1989, p.27).

Assim começa a primeira descrição da terceira linha de mudança: a preocupação com a higiene e a aparência pessoal, a troca de casca. Após o banho, ele pede um pente para desembaraçar 
os longos cabelos e "se distraiu olhando os braços, as pernas, os pés, parecia não acreditar que eram dele, fazia tempo que não os via sem o cascorão." (VEIGA, 1989, p.29).

Quando a nova comunidade começa a tomar corpo, com a chegada de novos e cada vez mais numerosos peregrinos, o Conselheiro decide abrir mão, definitivamente, de sua imagem de beato e líder messiânico. Manda Bernabé encontrar um alfaiate e encomendar duas mudas de roupa "para ele se apresentar como todo mundo e não chamar atenção". E a decisão de cortar a barba também adquire, tal qual o banho, caráter purificador, pois era justificada pelo fato de que o "dono dela, para todos os efeitos, estava enterrado em Canudos ${ }^{3 \prime \prime}$ (VEIGA, 1989, p.89).

"Mudar de casca". Além de no título da obra, a expressão e suas variações aparece quatro vezes: "fazia tempo que não os via sem o cascorão" (p.29); "Era preciso soltar a casca antiga" (p.102); "mudar de casca, trocando a barba, o camisolão de zuarte e o bordão de pastor por uma cara lisa, cabelo curto e roupa comum de sertanejo..." (p.118); "Marigarda ao vê-lo de repente na nova casca" (p.119); "O morto continua vivo. Apenas mudou de casca e de nome" (p.134). E também na narrativa do sonho do Conselheiro em que um rei ou imperador lhe mostra uma "árvore de casca grossa escamosa" (p.129), onde percebe-se também uma alusão à serpente do título.

3 É verdade que o próprio autor vai minimizar a importância simbólica do corte da barba ao escrever, na página 119, que o Conselheiro decidiu cortar a barba "não pelo desejo de mudar de aparência, mas para se livrar de uma carga de piolhos que não o vinha deixando dormir nem sossegar". Mas ridicularizar as situações que possam remeter a símbolos ou possuir grandes significados é típico da escrita de Veiga neste romance, como as "inspirações" provocadas por situações escatológicas, ou os sonhos e visões que não levam a nenhuma conclusão. 
Assim, completam-se os três estágios da troca de casca do Conselheiro. De líder despótico à democrata, de líder religioso a gestor de uma comunidade laica, da imagem de profeta ao homem comum. O coroamento deste processo é a mudança do nome. Não mais Antônio Conselheiro, mas, singelamente, tio Antônio.

\section{CROSSOVER}

Como já havíamos mencionado, a partir da página 89 a história alternativa criada por José J. Veiga começa a fazer uso da ficção recursiva, promovendo verdadeiro desfile de personagens históricos, cujas aparições são, aparentemente, despropositadas. Mas o despropósito não é isento de objetivo. A verossimilhança é sacrificada em prol de uma ideia, como veremos adiante.

Os primeiros a entrar em cena são dois revolucionários irlandeses, Séamas Ó Conghaile e Pádraig Anraí Mac Piarais, ou, em inglês, James Connolly e Patrick Pearse. Veiga propõe um quebra-cabeça para o leitor, pois esses personagens não são de fácil identificação. A primeira pista é o modo como os sertanejos entendem seus nomes. Um deles é compreendido como "Cotenile", e de fato é como soa o gaélico Conghaile. Já o segundo, "Pião Dó", é uma corruptela algo forçada de Pádraig Piarais, que pronuncia-se mais ou menos como Póud-rik Pir-ésh. Mas o efeito cômico é irresistivel.

Os irlandeses entram na história para civilizar a nova Canudos. Trabalhadores e criativos, conhecedores de várias técnicas, cedo despertam a inveja dos sertanejos. Para não serem vítimas de maledicências e também para procurar ferramentas, apetrechos e veículos para as obras necessárias do arraial, resolvem sair sem destino pelo sertão. É nesse momento da narrativa (e mais tarde, 
quando do encontro com o fotógrafo Militão) que José J. Veiga constrói a história contrafactual dos revolucionários, inventando fatos e embaralhando datas e lugares.

Estas vidas imaginárias são narradas no início de sua jornada, quando eles rememoram uma promessa não cumprida feita a outro irlandês, de nome Roger, de ajudá-lo na Costa do Níger, na África. Trata-se de Roger Casement (Ruairí Dáithí Mac Easmainn), que foi cônsul britânico no Congo (e não na Costa do Níger) em 1903, ou seja, pelo menos cinco anos depois dos eventos relatados no romance. Depois, lamentam estar a "ambular em terra estranha", em vez de voltar para a Irlanda ajudar Parnel (sic), Charles Stewart Parnell, líder político nacionalista irlandês que morreu em 1891, pelo menos sete anos antes. Em seguida encontram no caminho Militão Augusto de Azevedo, pioneiro da fotografia brasileira, que exerceu o ofício até 1885 , quando vendeu o seu estúdio e despediu-se da profissão lançando álbuns que registravam a vida urbana em São Paulo, em 1887, dez anos antes. Nunca esteve no sertão nordestino.

Ainda sobre Roger Casement, Cotenile e Pião Dó explicam a Militão que ele escrevia relatórios sobre as crueldades dos ingleses na Costa do Níger mas não se importava com o sofrimento de seus compatriotas na Irlanda, sob o jugo dos mesmos ingleses. Na verdade, Casement escreveu o famoso Casement Report sobre as atrocidades do rei Leopoldo II da Bélgica no Congo, e quando voltou para a Irlanda em 1904 juntou-se aos nacionalistas e passou a trabalhar pela independência de seu país, até ser enforcado pelos ingleses em 1916, acusado de alta traição por negociar com os alemães em plena guerra mundial ${ }^{4}$.

$4 \mathrm{Na}$ mesma ocasião, Connolly e Pearse foram fuzilados por sua participação na Insurreição da Páscoa, com apenas alguns meses de antecedência. 
Os dois revolucionários continuam a narrar suas aventuras. Da África para a Bahia e da Bahia para o Amazonas. No Amazonas conhecem o poeta Sousândrade. Este de fato esteve lá, mas em 1858, quando Connolly e Pearse sequer eram nascidos. Estes últimos prosseguem em sua jornada e Militão, fascinado pela perspectiva de conhecer sobreviventes de Canudos, incluindo o próprio Conselheiro, toma o rumo oposto.

Militão chega ao arraial, introduz o Conselheiro nos mistérios da arte fotográfica e registra sua "nova casca" para a posteridade, ainda que anônima.

O desfile recursivo continua. Chegam ao arraial nada mais, nada menos que Chiquinha Gonzaga acompanhada do Dr. Orville Adalbert Derby. A presença da musicista é um mistério. Nada a justifica a não ser um capricho insondável do autor. Nenhuma leitura, por mais extravagante, pode ser feita de maneira satisfatória. Se mistério é, que o mistério permaneça para futuras investigações. Diferentemente, o Dr. Orville é, no romance, talvez o elemento de recursividade mais interessante, e nem por isso melhor explorado. Derby e Euclides da Cunha conheceram-se em 1896, quando participaram de uma comissão para investigar um suposto vulcão na cidade de Santos. No ano seguinte, Derby foi um dos autores da proposta de filiação de Euclides ao Instituto Histórico e Geográfico de São Paulo. Além disso, Derby escreveu trabalhos como "Contribuição para o estudo da geologia do vale do rio São Francisco" (1879), que foram fundamentais para Euclides escrever as partes iniciais de Os Sertões (SANTANA Apud FERNANDES, 2002). Sua presença no romance de Veiga é pouco mais que figurativa e o livro que ele teria escrito sobre as "estruturas rochosas da Bahia, 
publicado pela Universidade de Wisconsin em 1906" é fictício. É o único personagem da porção recursiva do romance que tem ligação com o universo de Canudos e Euclides da Cunha.

Finalmente, Pyotr Kropotkin, o anarquista Pedro, o deus ex machina do livro, que surge das estepes para o sertão apenas para ajudar o ex-Conselheiro, agora tio Antônio, a elaborar o projeto da nova comunidade, antes de voltar repentinamente para sua Rússia natal, corroído pela nostalgia e por preocupações políticas. O projeto que eles elaboram é, evidentemente, uma comunidade anarquista, uma "sociedade sem governo". No fim do romance, é dito que a Concorrência de Itatimundé prosperou e "serviu de modelo a uma infinidade de outro mundo afora", e que teria sido tão bem-sucedida que precisou ser demolida à força, "como fora Canudos setenta anos antes".

Quem demoliu a nova Canudos? Uma pista é dada: nesta ocasião, uma estátua do tio Antônio "que completava o visual da praça principal da Concorrência, foi dinamitada pelos invasores em 1965 e seus pedaços jogados serra abaixo".

\section{A RETIFICAÇÃO DA HISTÓRIA}

Em uma entrevista concedida para uma dissertação acadêmica sobre sua obra, José J. Veiga declara que os seus romances do assim chamado "Ciclo Sombrio"5, escritos depois de 1964, sofreram contaminação do clima político da época. Mas depois ele "estava precisando escrever livros menos sombrios, e o tempo que fazia no momento permitiu que entrasse sol neles. É o que

5 Romances em que o autor expressava a sua percepção da atmosfera da ditadura de 1964: Sombras de Reis Barbudos, Os Pecados da Tribo e Aquele Estranho Mundo de Vassabarros. 
espero fazer daqui para diante, se puder" (SOUZA, 1987, p.167). Um pouco antes, comentando esses romances escritos no tempo da ditadura militar, afirmou:

Qual será a atitude verdadeiramente revolucionária de um escritor: mostrar ficcionalmente uma população oprimida reagindo e acabando com a opressão (uma mentira), ou mostrá-la sofrendo resignadamente? Esses livros foram escritos para desassossegar, e achei que se mostrasse os oprimidos derrubando as bastilhas, o leitor fecharia o livro aliviado, e não desassossegado. Um livro pouco pode fazer para corrigir injustiças: se conseguir causar desassossego, já conseguiu alguma coisa. Não acredito que a massa humana esteja condenada à submissão eterna. Ela seria submissa só enquanto não decidir mudar a situação. As forças que submetem as massas não vão nunca "pôr a mão na consciência" um dia e soltá-las. Elas só "largarão o osso" se não puderem mais segurá-lo. E quem vai forçá-las a "largar o osso"? Os próprios escravos. É uma lição da História. Toda melhoria no plano político-social tem que ser tomada. Isso vale no plano interno e no plano externo. As nações que hoje estão pisando no pescoço de outras só vão tirar o pé quando os espezinhados se mexerem. (SOUZA, 1987, p.166)

Percebe-se que, em $A$ casca da serpente, escrito dois anos depois desta entrevista, de fato o "sol entra", e, a princípio, não é um romance "sombrio". Ele inaugura a ucronia ficcional na literatura brasileira. Não se contenta em ser apenas uma história alternativa do fim da Guerra de Canudos, também promove uma linguagem alternativa em relação à Os Sertões: possui generosas doses de humor, afetividade pelos personagens e linguagem simples e pitoresca, cheia 
de expressões regionais cuidadosamente coletadas, distantes das antíteses, paradoxos e oximoros do estilo euclidiano.

No entanto, o Ciclo Sombrio paira sobre o livro. A leitura que vamos propor é que José J. Veiga sintetizou a história de um Brasil que poderia ter sido bem-sucedido se os militares de 1964 não tivessem interrompido o processo. Nesta síntese, vemos um velho Brasil, representado pela velha Canudos, monarquista e religiosa, modernizar-se pela adoção de um sistema democrático e laico, onde a religião perde a sua importância, etapa na qual a presença dos revolucionários republicanos da Irlanda é fundamental. O objetivo final é a superação deste estágio pela configuração de uma sociedade sem governo e sem religião, anarquista, etapa em que fundamental é a presença de Pyotr Kropotkin, um sonho "que deu tão certo que precisou ser demolido à força" (VEIGA, 1987, p.154).

A metáfora parece-nos óbvia. A história de Canudos "retificada" é a história retificada do Brasil. É a história que os socialistas e utopistas que apoiavam as reformas do governo João Goulart, por considerá-las um passo necessário para reformas mais profundas e radicais, queriam ver escrita. Veiga parece resgatar as interpretações marxistas de Rui Facó (1963) e Edmundo Moniz (1978) sobre o suposto socialismo utópico de Canudos, para idealizar o sonho de tio Antônio, que também era o seu sonho e o de sua geração. 0 sol se levanta. Mas, fiel ao princípio que enunciara na entrevista a Agostinho Potenciano de Souza, ele escreve para "desassossegar". Consequentemente, sua utopia deveria ser destruída. E quem a destrói são os militares de 64, em 65. 
Na mesma entrevista, mencionada acima, o autor demonstra bastante irritação com a construção das usinas nucleares no período da ditadura (SOUZA, 1987, p.170). Dois anos depois, ele finaliza $A$ casca da serpente de modo um tanto caricato, mas pagando singelo tributo a um dos lugares - comuns da ficção científica, onde é dito que o arraial se transformou em um "depósito de lixo atômico administrado por uma indústria química com sede fictícia no Principado de Mônaco" (VEIGA, 1987, p.155).

\section{A RETIFICAÇÃO DO MUNDO: DEUS E O DIABO NA TERRA DO SOL}

Já vimos que tanto a democratização quanto a laicização do novo arraial foram impostas pelo Conselheiro. Para a ideia evoluir em direção a uma sociedade sem governo, tio Antônio e Kropotkin passam a discutir e escrever compulsivamente e "verrumar projetos estrambóticos". Quando Kropotkin decide retornar a Rússia, eles continuam se correspondendo. O resultado é, além de um livro que o anarquista publica na França no qual expõe suas ideias, oriundas das longas conversas noites adentro com tio Antônio, a própria Concorrência de Itatimundé, sua materialização.

Agora, à guisa de conclusão, tentemos vislumbrar algumas implicações mais profundas que o texto nos sugere, independentemente das intenções do autor, quanto ao real significado deste raiar do sol, desta "retificação do mundo", desta "troca de casca".

Na ocasião em que os irlandeses partem do arraial em sua expedição, Marigarda passa a ser vítima da maledicência geral por conta de uma suspeita de um romance entre ela e Cotenile. O povo da comunidade resolve pregar uma peça na pobre, escondendo os 
pertences dele para ela pensar que havia sido abandonada. É dito que os homens

já a olhavam com pena, mas pela maldade natural das pessoas ninguém desmanchava o esquema, todos queriam que ela penasse o máximo, inclusive tio Antônio, que agora era uma pessoa como as outras, interessada em criar embaraços para ver como o padecente os enfrentaria. Exatamente como faz Deus (VEIGA, 1987, p.123)

Esse trecho do romance é bastante significativo, pois nos faz pensar, a partir da aparente contradição entre ser "uma pessoa como as outras" e fazer "exatamente como faz Deus", no significado real do título do livro. Se o Conselheiro trocou de casca, o Conselheiro é a serpente ${ }^{6}$. E o que é a serpente? É um símbolo ambivalente, tanto no cristianismo como em outras culturas e religiões. Mas existem indícios no romance que remetem à simbologia judaico-cristã no Livro do Gênesis. O que diz a serpente do Jardim do Éden ao primeiro casal, quando os instiga a comer o fruto da árvore do conhecimento?

Não, não morrereis, não morrereis

pois Elohîms sabe que no dia em que dele comerdes vossos olhos se arregalarão

e sereis como Elohîms,

penetrando o bem e o mal. (CHOURAQUI, 1995, p.59-60)

6 Em uma dissertação de mestrado defendida na UESB em 2010, Marleide Santana Paes observa que o incidente do acauã matando a cobra (VEIGA, 1987, p.106-107), testemunhado pelos irlandeses, é uma metáfora das quatro expedições militares contra Canudos. O acauã ataca três vezes e só na quarta investida arranca a cabeça da cobra, em uma alusão a decapitação do Conselheiro. 
Sereis como Deus. E conhecereis o bem e o mal. No já citado episódio da desistência da construção da igreja, Sinfrônio levanta a hipótese de que às vezes "a pessoa para ser boa precisa se fazer de ruim". E ninguém entendeu essa teoria, "para eles muito nova". Mas tio Antônio entendeu, e decidiu não mais ser um portador da palavra de Deus, mas agir como o próprio Deus, acima do bem e do mal. E é exatamente assim que os ideólogos de utopias revolucionárias, autoglorificados por uma aura de messianismo político, consideram a si mesmos. Neste caso, é pertinente recordar os paralelismos entre a Serpente e o Titã, entre a narrativa bíblica e o mito de Prometeu (DIEL, 1991, p.223), um mito caro aos primeiros apóstolos da fé revolucionária, como explica o historiador James H. Billington:

Um modelo de mito recorrente para os revolucionários - os primeiros românticos, o jovem Marx, os russos do tempo de Lênin - foi Prometeu, que roubou o fogo dos deuses para o uso da humanidade. A fé prometéica dos revolucionários assemelhava-se em muitos aspectos à crença moderna generalizada de que a ciência levaria os homens das trevas à luz. Mas havia também o pressuposto mais agudo e milenar de que, no novo dia que estava amanhecendo, o sol nunca iria se por. (BILLINGTON, 1980, p.6)

E, como para reforçar o ponto de vista aqui defendido, José J. Veiga nos brinda, na página 127, com o interessantíssimo relato de um sonho do Conselheiro, no qual um rei ou imperador mostra-lhe uma "árvore de casca grossa escamosa, que dá flores amarelas em forma de espiga, e como fruta uma vagem achatada, meio curva", árvore essa cuja flor daria mel, cuja vagem poderia 
servir de alimento, cuja madeira serviria para tudo, e cujas folhas alimentariam os animais. E o rei recomenda ao Conselheiro plantar essa árvore em Itatimundé.

Ao ouvir o relato do sonho, Cotenile lembra de uma árvore parecida que ele viu no Peru, mas cujo nome não recordava. 0 assunto foi logo esquecido.

Essa árvore é a Prosopis juliflora, da família das leguminosas, conhecida como algaroba. Originária do deserto do Piúra, no Peru, foi introduzida no sertão de Pernambuco na década de 40 do século XX, por sua excelente capacidade de adaptação às regiões áridas e semiáridas. Desenvolve-se bem em solos de baixa fertilidade, necessita pouca água e possui todas as qualidades mencionadas pelo rei no sonho do Conselheiro. É muito apreciada pelo sertanejo, que considera suas propriedades como "mágicas". Por ser espécie exótica, e por sua grande adaptabilidade, tornou-se uma praga, ao ponto de sua proliferação ser considerada "o mais grave fenômeno de invasão biológica de uma espécie exótica sobre a vegetação da caatinga" (PORTAL EMBRAPA, 2008).

Essa espécie alienígena, essa árvore que tudo promete mas termina por se tornar uma praga que tudo corrói: exatamente como a fé revolucionária e prometeica, o sonho de um mundo retificado, passado a limpo. E é neste sonho que a figura de Tio Antônio é transmutada e imortalizada em granito, uma estátua em que o Homem e a Terra se fundem, imagem da Luta, o tronco do Conselheiro "como árvore robusta...os pés se confundindo com as raízes, os membros se confundindo com as asperezas da casca" (VEIGA, 1987, p.155). A casca da Serpente. 
Existe um exemplar de uma espécie de Prosopis no reino do Bahrein, com quatrocentos anos de idade. Arqueólogos encontraram artefatos nas cercanias desta árvore que parecem remontar ao período de uma antiga civilização que os sumérios chamavam de Dilmun, a "terra do sol nascente", o País dos Vivos mencionado no Épico de Gilgamesh. Nesta terra mítica, existiu um jardim que alguns estudiosos relacionam com o Jardim do Éden. (PAGE, 2010).

Esta árvore centenária é conhecida pela população local como Árvore da Vida.

\section{REFERÊNCIAS}

ALDISS, Brian (1988). Frankenstein libertado. Lisboa, Livros do Brasil.

ASIMOV, Isaac (1988). "Introdução". In TURTLEDOVE, Harry . O Agente de Bizâncio. Lisboa, Livros do Brasil.

BILLINGTON, James H. (1980). Fire in the minds of men. New York, Basic Books. BORGES, Jorge Luis (2000). Um ensaio autobiográfico. São Paulo, Globo. (1999). "História Universal da Infâmia". In Obras Completas Vol. I (1923 - 1949). São Paulo, Globo.

CHEVALIER, Jean; GHEERBRANT, Alan (1998). Dicionário de Símbolos. Rio de Janeiro, José Olympio.

CHOURAQUI, André (1995). No princípio (Gênesis). Rio de Janeiro, Imago.

CLUTER, John NICHOLS, Peter (1999). "Recursive SF" In The Encyclopedia of Science Fiction, Orbit Books. In http://www.sf-encyclopedia.com/entry/ recursive_sf Acesso em 19.Mai.2018.

CUNHA, Euclides da (2001). Os Sertões, São Paulo Ateliê Editorial.

DIEL, Paul (1991). O simbolismo na mitologia grega. São Paulo, Attar. In https://www.embrapa.br/busca-de-noticias/-/noticia/18035980/ambientepreservado-evita-invasao-do-bioma-caatinga-pela-algarobeira-Acesso em 19.Mai.2018. 
EMBRAPA (2008). In https://www.embrapa.br/busca-de-noticias/-/ noticia/18035980/ambiente-preservado-evita-invasao-do-bioma-caatingapela-algarobeira- Acesso em 19.Mai.2018.

EVANS, Richard J. (2014). "Altered Pasts: Counterfactuals". In History. The Menahen Stern Jerusalem Lectures. Lebanon. Brandeis University Press.

. (2014). "O passado que não aconteceu". In BBC HISTORY Brasil, n. 2. São Paulo. Alto Astral.

FACÓ, Rui (1963). Cangaceiros e fanáticos. Rio de Janeiro, Civilização Brasileira.

FERGUSON, Niall (1999). "Virtual History: Towards a 'chaotic' theory of the past". In . Virtual History, Alternatives \& Counterfactuals. New York, Basic Books.

LEWIS, Anthony R. "Recursive Science Fiction"In http://www.nesfa.org/ Recursion/recursive_Introduction.htm Acesso em 19.Mai.2018.

GOMES, Renato Cordeiro (2006). "O histórico e o urbano: sob o signo do estorvo". In Revista de Literatura Comparada. Rio de Janeiro.

LODI-RIBEIRO, Gerson (2003). Ensaios de História Alternativa. Scarium e-book.

MONIZ, Edmundo (1978). Guerra Social de Canudos. Rio de Janeiro, Civilização Brasileira.

NEVINS, Jess (2003). Heroes and Monsters: The Unofficial Companion to the League of Extraordinary Gentlemen. Monkeybrain.

NOGUEIRA, Ataliba (1978). Antônio Conselheiro e Canudos. São Paulo, Editora Nacional.

OLIVEIRA, Cristiano Mello de (2014). "O romance histórico brasileiro na atualidade". In Revista Vozes dos Vales, 3(6), UFVJM.

PAES, Marleide Santana (2010). A memória do tio Antônio à sombra do Conselheiro de Euclides da Cunha. Vitória da Conquista, UESB.

PAGE, Lewis (2010). "Lost ancient civilisation's ruins lie beneath Gulf, says boffin". In http://www.theregister.co.uk/2010/12/09/ancient_dilmun_garden_ eden_gulf_lost_civilisation/\%20 Acesso em 19.Mai.2018. 
ROSE, Jeffrey I. (2010). "New Light on Human Prehistory in the Arabo-Persian Gulf Oasis". In Current Anthropology 51(6).

RYAN, Marie-Laure (2013). "Narrativa Transmídia e Transficcionalidade". In http://www.mariantonia.prceu.usp.br/celeuma/?q=revista/3/dossie/narrativatransm\%C3\%ADdia-e-transficcionalidade Acesso em 19.Mai.2018.

SANTANA, José Carlos Barreto de (2002). "A Construção do Discurso Científico de Euclides da Cunha: Análise da Geologia em Os Sertões". In FERNANDES, Rinaldo de. O Clarim e a oração: cem anos de Os Sertões. São Paulo, Geração Editorial. SAINT-GELAIS, Richard (2010). "Transfictionality". In HERMAN, David, JAHN, Manfred \& RYAN, Marie-Laure. Routledge Encyclopedia of Narrative Theory. London and New York, Taylor \& Francis e-Library.

SCHWOB, Marcel (1997). Vidas Imaginárias. São Paulo, Editora 34.

SOUZA, Agostinho Potenciano de (1987). Um olhar crítico sobre nosso tempo (uma leitura da obra de José J. Veiga). Unicamp.

VANDERMEER, Jeff, CHAMBERS, S.J. (2011). The Steampunk Bible. Nova York, Abrams Image.

VEIGA, José J. (1989). A casca da serpente. Rio de Janeiro, Bertrand Brasil. 